\title{
The Effect of Using Fuel Type on Exhaust Gas Emission of K3VE Gasoline Engine Whith Compression Ratio 11:1
}

\author{
Suherman $^{1}$, Khoiri $^{2}$, Andi Bahar ${ }^{3}$ \\ \{*suhermanus@unimed.ac.id \} \\ Universitas Negeri Medan, Medan Indonesia ${ }^{1}$
}

\begin{abstract}
This study aims to determine the effect of using fuel types (premium, pertalite, and pertamax) on the composition of the exhaust gas engine $\mathrm{K} 3 \mathrm{VE}$ with a compression ratio of 11: 1 . The independen variabels in this study are (1) premium fuel with the value of Research Octan Number (RON) 88, pertalite with the value RON 90, and pertamax with the value of RON 92. The dependen variable of this research are the composition of the exhaust gas. The data in this study were obtained from testing the use of each fuel on the K3VE gasoline engine with a gas analyzer at the Unimed Engineering Faculty of Automotive Engineering Laboratory. Testing for each type of fuel is carried out six times. Test results of the data using each type of fuel are analyzed; (1) descriptively; and (2) different tests using the Mann-Whitney Test. The results obtained show (1) the use of premium fuels, pertalite and pertamax produce CO mean concecutive: $0.02 \%, 0.01 \%$ and 0\%; HC mean: 124 ppm, $81.2 \mathrm{ppm}$ and $17.3 \mathrm{ppm}$; CO2 mean 14\%, 13.1\% and $13.1 \%$ respectively; (2) There are significant differences between the average premium CO, pertalite, pertamax and $\mathrm{HC}$ premium, pertalite and pertamax, the lowest is for the use of pertamax
\end{abstract}

Keywords: Premium, pertalite; petamax; exhaust gas emissions.

\section{Introduction}

Fuel is an important factor in vehicles, the use of this type of fuel needs to be adjusted to the design technology and specifications of the vehicle engine. For a gasoline motor, one of the determinants is the size of the compression ratio. Comparison of compression is a comparison of the volume of space above the piston when the piston is at the Below Dead Centre (BDC) with space above the piston when the piston is at the Top Dead Centre (TDC). For gasoline engines in general the compression ratio ranges from 7: 1 to 12: 1 depending on the type of vehicle or design from the manufacturer. The cars that have been produced lately, the compression ratio tends to be made high with the aim of increasing efficiency (fuel economical), and reducing the level of exhaust emissions. Consequently a high compression ratio in order to obtain a combustion process that produces optimum performance, must use fuel with the appropriate Research Octane Number (RON).

The higher the compression ratio of a vehicle requires high RON fuel. RON is a number that shows how much maximum pressure can be given inside the combustion chamber before the gasoline burns spontaneously. Inside the combustion chamber, a mixture of gasoline and air can burn itself spontaneously before being exposed to a spark from the spark plug, this is 
an undesirable condition. The higher the number of RON gasoline, the longer the gasoline burns spontaneously. This spontaneous combustion causes a knock inside the machine which is commonly referred to knocking symptoms. The occurrence of spontaneous combustion is not desirable because combustion occurs not as designed by the manufacturer. Spontaneous combustion in addition will reduce vehicle performance, damage engine components and produce high emissions of pollutant gases including $\mathrm{CO}, \mathrm{HC}, \mathrm{CO} 2$ and $\mathrm{NOx}$ (Toyota Astra Motor, 2008). Therefore, it is recommended that the use of fuel must be adjusted to the engine specifications, especially the compression ratio of the engine. In Indonesia, Pertamina has provided several alternative fuel choices for gasoline vehicle, among others: premium with RON 88 which is the cheapest price, pertalite with RON 90, pertamax with RON 92 and pertamax turbo with RON 95. Higher octane value of fuel, price more expensive.

K3VE machines in Indonesia include vehicles that have many users. This car has a compression ratio of 11: 1, fuel system Electronic Fuel Injection (EFI), ignition system, Electronic Spark Edvancer (ESA), and valve opening system Variable Valve Timing Intelligence (VVTi). The operation of the above systems is regulated by the Electronic Control Unit (ECU) and uses Catalyc Converter to neutralize exhaust emissions.

Cars with a compression ratio of 11: 1 are designed to use fuel with RON 92, in Indonesia, namely pertamax (http: // www. Rider galau.com (http://www.ridergalau.co./maupilih-premium-pertlite-pertamax-pertamax-plus. Accessed on May 15, 2017), but the reality is there are still those who use premium fuel with RON 88 or pertalite with RON 90, considering the cheaper price of RON 92 fuel.

[2] Based on the background stated above, the formulation of the problem of this research are: (1) What is the composition of the K3VE engine exhaust emissions with a compression ratio of 11: 1 that uses premium fuel with RON 88; (2), pertalite with RON 90, and pertamax with RON 92. (2) Is there a difference in exhaust emissions between those using premium, pertalite and pertamax?

\section{Methodology}

Premium [3] is a clear yellowish distillate type fuel oil. Premium is one of the fuel for motorized vehicles in Indonesia. Premium in Indonesia is marketed by Pertamina at a relatively cheap price because of its low quality and obtaining subsidies from the Government. Premium is fuel oil with RON 88 (Indonesian Wikipedia, the free encyclopedia). Pertalite is the latest fuel from Pertamina with RON 90. Pertalite is produced by the addition of additives in the processing process at oil refineries. Pertalite was launched on July 24, 2015 as a new variant for consumers who want higher quality premium fuel oil, but at a lower price than Pertamax, this type of fuel is a mediator between Premium and Pertamax. To make Pertalite the composition of the material is nafta which has RON 65-70, so that the RON becomes RON 90 then mixed with HOMC (High Octane Mogas Component), HOMC can also be called Pertamax, mixing HOMC that has RON 92-95, but also added EcoSAVE additives. This EcoSAVE additive is not for increasing RON but for the engine to become finer, cleaner and more efficient (Indonesian Wikipedia, the free encyclopedia).

Pertamax is a Pertamina fuel oil product. Pertamax, like Premium, is a fuel oil product from petroleum processing. Pertamax is produced by the addition of additives in the processing process at oil refineries. Pertamax in Indonesia was first launched on December 10, 1999 as a Premix replacement and Super TT because MTBE elements are harmful to the 
environment. Pertamax is recommended for vehicles that have compression from 9.1 to 10.1 , especially those that have used technology equivalent to Electronic Fuel Injection (EFI) and catalytic converters (Wikipedia, the free encyclopedia).

The K3VE engine is a 4-stroke gasoline engine with an Electronic Fuel Injection (EFI) fuel system, valve opening with intelligent Variable Valve Timing system (VVTi) and using a catalyst converter as a cleaner for exhaust emissions. This engine fuel system, ignition, valve opening and closing settings are regulated by the Electronic Control Unit (ECU). ECU functions to receive signals from various sensors and process them by trying to compare them with the optimal values that already exist in the ECU program, then instruct the actuator to work. The actuator in the EFI system is an injector that sprays fuel with the duration according to the ECU calculation, while the ignition system is an igniter that regulates the appearance of ignition on the spark plug (Toyota Astra Motor, 2008).

The EFI system chart on gasoline engines is generally shown in figure 1.

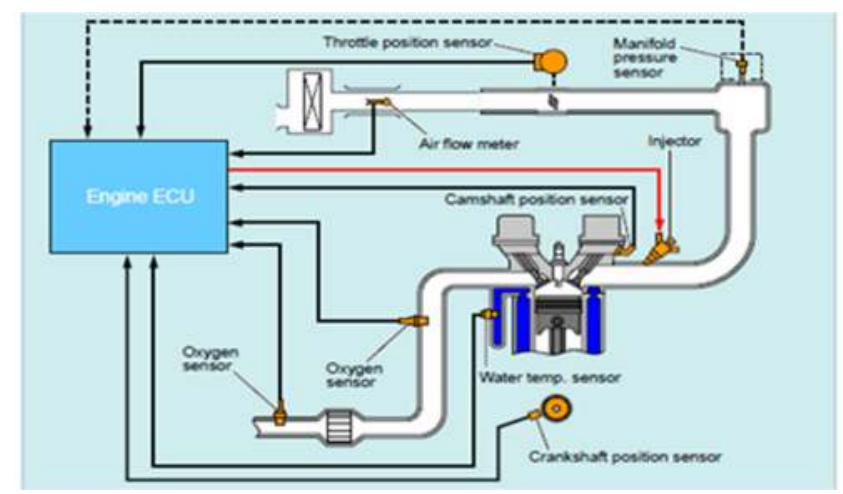

Fig. 1. EFI System Chart

In the EFI system, fuel is supplied to each injector after ECU calculates the duration of fuel injection based on signals from sensors. The sensors are: water flow meter or manifold pressure sensor, K3VE machine including type L EFI uses air flow meter, this sensor detects the air mass that will enter the combustion chamber; crankshaft position sensor, detects the crankshaft angle and engine speed; camshaft position sensor, detects the standard camshaft timing angle; water temperature sensor, detects coolant temperature; throttle position sensor, detects the opening angle of the throttle valve; and oxygen sensor, detecting oxygen concentration in the exhaust gas. Thus the duration of the fuel injection sprayed by the injector into the combustion chamber is adjusted to the condition of the engine received by the ECU based on engine working conditions.

To get performance and exhaust gas with low emissions, the fuel injected into the combustion chamber must be burned at the right time by the ignition system. The K3VE engine uses an Electronic Spark Advancer Direct Ignition System (DIS). In general, the chart of the ESA ignition system is shown in Figure 2. 


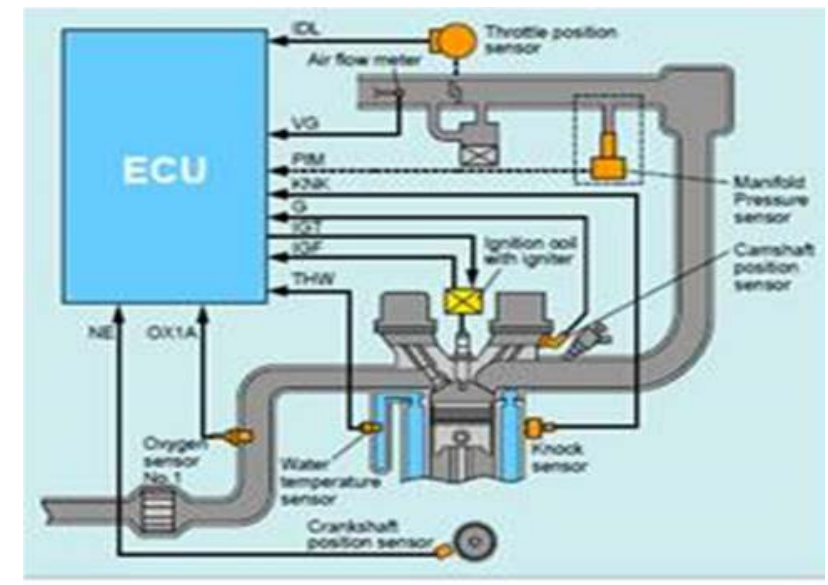

Fig. 2. ESA Ignition System Chart

The chart shows that ignition with ESA is done after the ECU receives signals from sensor. Knock sensor signals the ECU if there is knocking. Knocking can occur when the fuel burns not as desired. Knocking shows that the occurrence of incomplete combustion will cause a decrease in performance and exhaust emissions that contain high pollutants. This condition can be caused by improper use of fuel, including machines with a high compression ratio but using low RON fuel. This is quite influential if the vehicle using conventional ignition, but needs to be tested to what extent the role of the ECU is able to calculate sensor signals, especially knock sensors so that the ECU can adjust the IGT ignition signal to igniter so that combustion that occurs in the combustion chamber does not deviate from the desired.

The combustion process in the cylinder is expected and will produce optimum performance and low exhaust emissions when combustion occurs as shown in Figure 3.

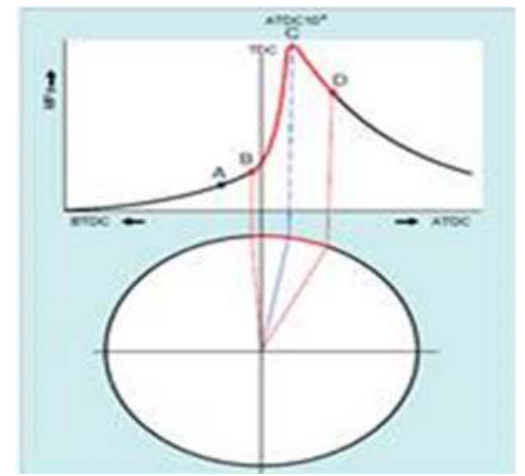

Fig. 3. Internal Combustion Pressure Cylinder

In the picture, point $\mathrm{A}$ is when the initial ignition matches the specifications of the vehicle and $\mathrm{B}$ starts burning fuel and the air in the cylinder, the A-B is called the ignition delay period. Point $\mathrm{C}$ is the maximum combustion. To get optimal performance, point $\mathrm{C}$ must be attempted to occur at $10^{\circ}$ after TDC. If point $\mathrm{C}$ is before or after $10^{\circ} \mathrm{TDC}$, the vehicle's performance will decrease and exhaust gas emissions will contain high pollutants. 
The results of combustion [4] of fuel and air in the combustion chamber will produce exhaust gas which consists of: (1) Hydrocarbons (HC), namely toxic particles from fuels that are not partially burned or burned. HC can cause respiratory problems, help form ozone, and is a major component in smog. The composition of $\mathrm{HC}$ can be suppressed by giving heat and oxygen outside the combustion chamber so that it reacts to Carbondiosida and water; (2) Carbon monoxide (CO), which is a gas that can be deadly, colorless and odorless, when inhaled it dissolves in the blood so it can reduce the ability to carry oxygen in the bloodstream. $\mathrm{CO}$ can be converted into $\mathrm{CO} 2$ with the help of a little oxogen and heat; (3) Nitrogen oxide (NOx) is produced by nitrogen and oxygen in mixed air and fuel. NOx occurs when the combustion chamber temperature rises more than $1800^{\circ} \mathrm{C}$. The higher the combustion temperature the higher the NOx. NOx can cause photochemical smog and if inhaled it can cause irritation to the nose and throat; (4) Carbon dioxide (CO2), which is a relatively harmless gas, $\mathrm{CO} 2$ concentration indicates the combustion process in the combustion chamber. If the Air Fuel Ratio (AFR) is in the ideal number, $\mathrm{CO} 2$ ranges from $12 \%$ to $15 \%$.

If the AFR is too rich or too thin, $\mathrm{CO} 2$ will drop, this gas emission is thought to cause global warming "greenhouse" effect.To control environmental health related to exhaust emissions of motorized vehicles, the Republic Indonesia Minister of Environment Regulation No. 5 of 2006 concerning the threshold for exhaust emissions of old motorized vehicles as shown in table 1 (Republic of Indonesia Environmental Regulation No. 5 of emissions of old motor vehicles.)

Table 1. Exhouse Gas Emission Threshold the Gasoline Vichicle

\begin{tabular}{lcccc}
\hline Category & Production & \multicolumn{3}{c}{ Parameter } \\
\cline { 3 - 5 } & Year & CO \% & HC ppm & Test Metod \\
\hline Gasoline & $<2007$ & 4,5 & 1200 & idle \\
Vichicle & $\geq 2007$ & 1,5 & 200 & \\
\hline
\end{tabular}

One of the efforts made by motor vehicle manufacturers to reduce environmental pollution due to exhaust gas, in vehicles paired with catalytic converters. Catalyc converter is a component that functions to convert harmful exhaust gases, especially $\mathrm{CO}, \mathrm{HC}$ and $\mathrm{NOx}$ gases into harmless gases into $\mathrm{H} 2 \mathrm{O}, \mathrm{CO} 2$ and $\mathrm{N} 2$ so that the exhaust gas that comes out becomes cleaner than pollutants. The hypothesis of this study is: The use of fuel with RON that is lower than the specifications will result in exhaust emissions with higher pollutant levels $(\mathrm{CO}, \mathrm{HC}$, and $\mathrm{CO} 2)$ than using fuel with $\mathrm{RON}$ according to specifications.

This study aims to determine the effect of using fuel types (premium, pertalite, and pertamax) on the composition of the exhaust gas engine K3VE with a compression ratio of 11: 1. This experimental research study examined the effect of the use of fuel types on exhaust emissions on the K3VE gasoline engine. The design of this study is shown in Table 2.

Table 2. Research Design

\begin{tabular}{|c|c|c|c|}
\hline Fuel Type & Premium & Pertalite & Pertamax \\
\hline $\begin{array}{l}\text { Exhaust Gas } \\
\text { Emissions }\end{array}$ & $\mathrm{O} \mathrm{HC} \quad \mathrm{CO}$ & DUC & $\mathrm{HC} \quad \mathrm{CO} 2$ \\
\hline
\end{tabular}

This research was conducted at the Automotive Engineering Laboratory Faculty of Engineering Unimed on Willem Iskandar Pasar V Medan Estate in October 2018.

As the object of this research is the K3VE gasoline engine exhaust gas which uses premium, pertalite and pertamax fuels. 
Independen variable this are (1) Type of fuel, which is premium with RON 88, pertalite with RON 90 and pertamax with RON 92. Dependen variables in this study is the composition of exhaust emissions ( $\mathrm{CO}, \mathrm{HC}, \mathrm{CO} 2$, and $\mathrm{O} 2$ ).

The data obtained were analyzed by: (1) descriptive for each treatment (type of fuel); (2) Mean difference test using the Mann-Whitney Test.

\section{Result and Discussion}

Tests are carried out on the same vehicle, the K3VE gasoline engine with different fuels, that is:

The first test, the vehicle filled with premium fuel, then tested the composition of the exhaust gas six times.

The second test, the fuel tank is drained and then filled with pertalite fuel, then run as far as $\pm 10 \mathrm{~km}$ so that the previous premium fuel which is still in the fuel line runs out, then resets on the ECU and runs again for $\pm 10 \mathrm{~km}$ then takes measurements of emissions exhaust gas as the first test six times.

The third test, the fuel tank is drained and then filled with pertamax fuel, then run as far as $\pm 10 \mathrm{~km}$, then reset the ECU and run again for $\pm 10 \mathrm{~km}$ and then measure the composition of the exhaust gas six times.

Data on exhaust emissions is obtained through measurement with a gas analyzer for each fuel. From the measurement results, data were obtained from $\mathrm{CO}, \mathrm{HC}, \mathrm{CO} 2, \mathrm{O}, \lambda$, and AFR.

Based on the results of testing of the use of each fuel is known that $\mathrm{CO}$ gas produced by the use of premium, pertalite, and pertamax is obtained a mean value of $0.02 \%, 0,01 \%$ and $0.00 \%$, HC values with $125 \mathrm{ppm}, 81.4 \mathrm{ppm}$ and $17.4 \mathrm{ppm}$ respectively. CO2 with an average value of $13.4 \%, 13.2 \%$, and $13.1 \%$, respectively. Pollutant values from the use of fuel above, all are still below the threshold specified in the Republic of Indonesia Regulation of the Living Environment No. 5 of 2006 concerning the threshold for exhaust emissions of old motor vehicles in Indonesia.

Hypothesis test results show that there is a significant difference between $\mathrm{CO}$ gas produced by the use of premium fuel with pertalite and pertamax, pertalite with pertamax, where the highest $\mathrm{CO}$ levels are those using mean premium $=0.02$ and pertamax $=0.00$

The HC element shows that there is a significant difference between HC elements produced by the use of premium fuel with pertalite and pertamax, pertalite with pertamax, where the highest $\mathrm{HC}$ content is premium Mean $=124 \mathrm{ppm}$ and the lowest use pertamax Mean $=17.3$.

The $\mathrm{CO} 2$ gas element shows no difference between those using premium, pertalite and pertamax fuels. The highest $\mathrm{CO} 2$ content is produced by premium use.

The test results showed that $\mathrm{CO}$ gas produced by the use of premium fuel was the highest, namely 0.02 , then pertalite 0.01 and pertamax 0.00 . CO gas is a polluting gas that can interfere with human health, because if inhaled it can react in the blood and inhibit the flow of oxygen in the blood. The value produced by the use of the three types of fuel above is still below the threshold, but it is better to use pertamax fuel which produces $\mathrm{CO}$ zero\%.

The HC test results show that the use of premium fuel produces the highest $\mathrm{HC}$, which is Mean of $124 \mathrm{ppm}$, pertalite an Mean of $81.2 \mathrm{ppm}$ and pertamax Mean $17.3 \mathrm{ppm}$.

Hydrocarbons (HC) [5], which are toxic particles from fuels that are not partially burned or burned. HC can cause respiratory problems, help form ozone, and is a major component in 
smog. Although this value is still below the permissible threshold, it is $150 \mathrm{ppm}$, but it is better to use pertamax fuel which only produces an average $\mathrm{HC}$ of $17.3 \mathrm{ppm}$.

The K3VE gasoline engine is a vehicle where the fuel system, ignition and valve opening are regulated by the Electronic Control Unit (ECU) and the catalyst converter has been installed. The results above show that the ECU has not been able to regulate when ignition and combustion in the cylinder which results in perfect combustion especially in premium use. It is known that the $\mathrm{HC}$ element which is large from the use of premium means that there are still many elements of fuel that are not burned. In addition, it is suspected that the catalytic converter has played a role in neutralizing pollutant emissions, but has not been able to neutralize exhaust emissions to the lowest level, especially in the use of premium fuel.

From the test results it is known that each fuel is burned with Air Fuel Ratio (AFR) $=14.6$ with an average value of premium $\lambda 0.994$, pertalite 0.995 , and pertamax 0.999 . The value of $\lambda$ is the value of the air ratio used for combustion compared to theoretical air. Theoretical $\lambda$ value $=1$. This result shows that the near perfect mixture of air and fuel occurs when using pertamax fuel, namely AFR $=0.999$.

\section{Conclusion}

Based on the test results, it can be concluded as follows:

a. The use of fuel with RON lower than the recommended. RON specifications will result in higher exhaust emissions with pollutants ( $\mathrm{CO}$ and $\mathrm{HC}$ ).

b. The use of fuel with lower RON than RON specification affects AFR, the mixture tends to be thin.

c. There are significant differences in $\mathrm{CO}$ exhaust emissions from the use of premium, pertalite and pertamax fuels. The Mean $\mathrm{CO}$ gas produced by the use of premium, pertalite, and pertamax fuels, respectively $0.02 \%, 0.01 \%$, and $0.0 \%$.

d. There is a significant difference in $\mathrm{HC}$ emissions from the use of premium, pertalite and pertamax fuels. The Mean HC value produced by the use of premium, pertalite, and pertamax fuels, respectively $124 \mathrm{ppm}, 81.2, \mathrm{ppm}$ and $17.3 \mathrm{ppm}$.

e. The use of fuel with a lower RON than the RON specification will produce exhaust gas with higher pollutants.

f. The ECU has not been able to manipulate the use of RON fuel under the specifications of the RON for perfect combustion.

g. The Catalyc converter on the gasoline engine K3VE is thought to have functioned to neutralize exhaust emissions, but not optimal in the use of fuel with RON lower than the specifications.

\section{References}

[1] http://www.ridergalau.com/mau-pilih-premium-pertalite-pertamax-pertamax-plus. Accessed on May 15, 2017.

[2] Indonesian Wikipedia, the free encyclopedia.htm.Accessed May 15, 2017.

[3] Toyota Astra Motor. (2008).Twenty One, Emissions. Automotive Training Materials.

[4] Toyota Astra Motor.(2008). Twenty One. ESA. Automotive Training Materials.

[5] Republic Indonesia Minister of Environmental Regulation No. 5 of 2006 concerning the threshold for exhaust emissions of old motor vehicles.) 